\title{
PENGARUH WARNA, TIPOGRAFI, DAN LAYOUT PADA DESAIN SITUS
}

\author{
Monica \\ Jurusan Desain Komunikasi Visual, Fakultas Komunikasi dan Multimedia, \\ Bina Nusantara University, Jln. K.H. Syahdan No 9, Palmerah, Jakarta Barat 11480 \\ monica@binus.edu
}

\begin{abstract}
Virtual world is now a mainstay many people promote themselves, goods, or their organizations. What is displayed in the virtual world associated with the role of a design is an interesting site and invites visitors to read and understand the message that the site owners want to convey. The design that attract not only in terms of its contents are complete but also in terms of appearance. This article describes a good selection of colors for a site, the application of typography for ease in reading the contents of site visitors, and a layout processing in accordance with the principles of design to design a site with well-ordered.
\end{abstract}

Keywords: layout, color, typography, web design

\begin{abstract}
ABSTRAK
Dunia maya saat ini menjadi andalan banyak orang dalam mempromosikan diri, barang, ataupun organisasi mereka. Apa yang ditampilkan di dunia maya tidak lepas dari peranan sebuah desain situs yang menarik dan mengajak pengunjung untuk membaca dan memahami pesan yang pemilik situs ingin sampaikan. Desain situs yang menarik tidak hanya dari segi isinya saja yang lengkap tetapi juga dari segi penampilannya. Artikel ini menjelaskan pemilihan warna yang baik untuk sebuah situs, penerapan tipografi untuk memudahkan pengunjung dalam membaca isi situs, dan pengolahan layout yang sesuai dengan prinsip desain agar desain sebuah situs tertata dengan baik.
\end{abstract}

Kata kunci: layout, warna, tipografi, desain situs 


\section{PENDAHULUAN}

Teknologi komputer di dunia ini menawarkan berbagai kesempatan bagi setiap orang atau instansi untuk mempublikasikan kegiatan, hasil karya, barang dagangan, ataupun komunitas mereka ke di dunia maya. Mereka makin merasa bahwa dunia maya memberikan kemudahan bagi mereka dalam memperkenalkan dan memasyarakatkan sesuatu secara lebih meluas, baik ke dalam negeri maupun ke luar negeri, dan mungkin tanpa batasan usia atau jenis kelamin. Setiap hal yang mereka lakukan di dunia maya tidak lepas kaitannya dari membuat halaman situs/ website yang baik dan menarik. Situs/ website yang telah ada memang dapat diubah desainnya menjadi lebih baik, tetapi tidak cukup hanya dengan sekedar mengganti desain latar belakangnya saja, atau jenis hurufnya saja, atau warna nya saja, karena dalam dunia desain situs yang terpenting tidak hanya dari segi pemrograman, isi situs, atau struktur informasinya saja namun harus mengkoordinasikan juga dari segi desain per halamannya, warna, tipografi atau jenis huruf, navigasi tombol, dan lain-lain.

Ada beberapa hal yang mempengaruhi keberhasilan suatu situs, diantaranya adalah (1) content atau isi, yaitu bentuk dan pengorganisasian isi dari situs tersebut dapat terbentuk dari bagaimana teks dituliskan dan ditampilkan secara terstruktur; (2) visual, mengarah ke layout/tata letak dari isi situs tersebut. Layout situs biasanya dibantu oleh beberapa software yang mendukung seperti HTML, CSS, Flash atau yang lainnya yang mendukung dekorasi atau navigasi untuk situs tersebut disertai dengan kepekaan estetika desain; (3) teknologi, mengarah pada software yang digunakan dalam membuat situs tersebut, misalnya HTML, CSS, atau Javascript, dan lain-lain; (4) kecepatan jaringan server, tergantung dari hardware atau software server-nya dan susunan jaringan yang ada; (5) tujuan, mengarah pada target dalam pembuatan situs tersebut, misalnya dikaitkan dengan topic ekonomi, atau untuk tujaun komersil atau yang lainnya. Hal ini memang perlu dipertimbangkan kecuali untuk situs personal yang lebih mengutamakan subjektifitas pribadi.

Sementara itu, pengelompokan situs secara umum adalah (1) situs informasi, menyediakan informasi seputar objek tertentu atau organisasi atau perusahaan tertentu. Jenis situs ini adalah yang paling umum dan di semua jenis situs lainnya pun pasti terdapat atau mencakup situs informasi di dalamnya; (2) situs transaksi, digunakan sebagai wadah untuk jual-beli termasuk di dalamnya adalah situs E-Commerce; (3) situs komunitas, menyediakan informasi atau transaksi yang berkaitan dengan fasilitas yang terfokus pada interaksi sesama pengunjung situs tersebut yang mempunyai kesamaan minat; (4) situs hiburan, termasuk di dalamnya permainan atau interaksi yang menarik dan mungkin juga terdapat transaksi atau komunitas atau informasi; (5) situs lainnya, situs artistik atau situs eksperimen atau situs personal (blog). Memang sulit sebagai desainer untuk menghubungkan pengunjung situs dengan pemilik situs agar tujuan yang diinginkan pemilik tersampaikan dengan jelas kepada pengunjung. Hal ini bisa tercapai apabila content/ isi situs tersebut menarik dan secara tampilan visual serta konsep juga menarik, nyaman dilihat, mudah dimengerti, dan mudah dalam navigasinya. Fungsi dan tujuan pembuatan situs saling berhubungan dengan tampilan desain situs tersebut. Jadi apabila fungsi dan tujuan dari situs tersebut jelas, maka akan mendukung ke segi desain yang akan menjadi lebih menarik. Begitu juga sebaliknya, desain yang baik akan dapat menyampaikan fungsi dan tujuan situs tersebut kepada pengunjung. Dan semua itu adalah menjadi tugas seorang desainer untuk mengolahnya.

\section{METODE PENELITIAN}

Penulisan menggunakan pendekatan studi kaji dengan melihat pengalaman-pengalaman dan pengamatan pribadi dan orang lain di lingkungan kerja desain situs. Selain itu didukung dengan studi literatur, yaitu mencari berbagai sumber yang terkait dengan dasar desain situs yang baik dari media cetak maupun media elektronik. Sumber informasi diseleksi, dievaluasi, dan dijadikan pendukung dalam penulisan ini. 


\section{HASIL DAN PEMBAHASAN}

\section{Warna}

Salah satu hal yang pertama kali ditangkap oleh pengunjung dari layar komputer mereka adalah warna. Warna menjadi salah satu media yang dapat menarik pengunjung untuk mengunjungi situs tertentu, untuk bertahan membaca isi informasi dalam situs tersebut, atau agar pengunjung mengerti apa yang disampaikan oleh pemilik situs.

Warna secara teori terbagi menjadi dua jenis yaitu warna additif dan warna substraktif. Warna additif adalah warna yang dihasilkan oleh cahaya. Digunakan pada televise atau layar komputer. Warna primer dari warna additif adalah red (merah), green (hijau), dan blue (biru). Perpaduan dari warna primer akan menghasilkan warna sekunder yaitu cyan (green + blue), magenta (blue + red), dan yellow (red + green). Perpaduan warna sekunder akan menghasilkan warna White (putih).

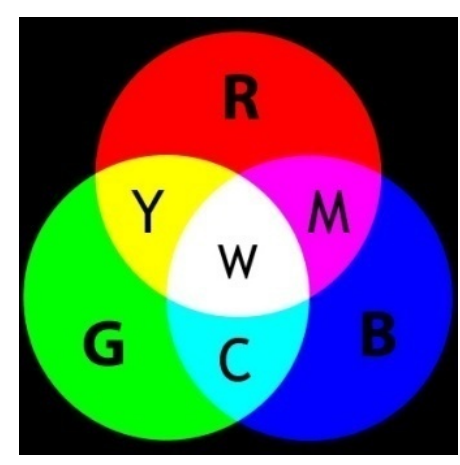

Gambar 1 Warna Additif

Warna substraktif adalah warna yang dihasilkan oleh pigmen (cat, pewarna, atau tinta). Warna primer dari warna substraktif adalah cyan (biru), magenta (merah), dan yellow (kuning). Perpaduan dari warna primer akan menghasilkan warna sekunder yaitu orange (red + yellow), green (yellow + cyan), dan purple (red + cyan). Perpaduan waran sekunder akan menghasilkan warna black (hitam).

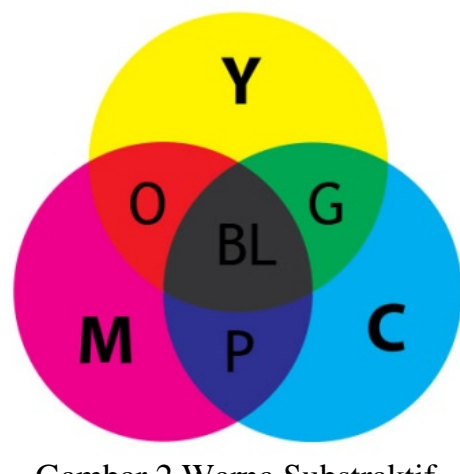

Gambar 2 Warna Substraktif

Ada beberapa contoh warna yang biasanya digunakan untuk keperluan desain situs beserta efek psikologis yang ditimbulkan dari warna-warna tersebut, yaitu (1) merah (red), berarti aktif, menyegarkan, menarik, kuat, energik, memikat, mendominasi, agresif; (2) merah muda (pink), berarti manis, lembut, perhatian; (3) ungu (violet), berarti maskulin, menarik, mistik, sensual, memikat, lembut, suram, sepi, kelam, menggelisahkan; (4) biru (blue), berarti terkontrol, misterius, intelektual, 
harmoni, tertutup, dingin, melankolis, dalam, setia, pemimpi, rasional, agresif; (5) hijau kebiruan (turqoise), berarti menyegarkan, jauh, egois, dingin, steril; (6) hijau muda (light green), berarti menggairahkan, beracun, mendorong; (7) hijau (green), berarti menyegarkan, harmonis, optimis, natural, tenang, lembut, damai, berkepribadian kuat; (8) kuning (yellow), berarti berwarna, terbuka, ceria, muda, hidup, penuh kesenangan, cerah, dangkal, melebih-lebihkan; (9) orange, berarti menarik, langsung pada tujuan, menyenangkan, hidup, komunikatif, hangat, intimidasi, bersemangat; (10) merah tua (dark red), berarti anggun, serius, berkelas tinggi; (11) hitam (black), berarti elegan, serius, netral, sedih, keras, jauh; (12) abu-abu (grey), netral, tidak gembira, kosong.

Warna juga dapat dibedakan menjadi warna hangat dan warna dingin. Warna hangat adalah warna-warna dari merah ke kuning, termasuk orange, merah muda, coklat, dan merah keunguan. Warna hangat memberi kesan panas dan bergerak atau dinamis, dan warna hangat ini akan terlihat lebih menonjol, lebih mendominasi dan dapat menjadi titik penekanan (emphasis) dalam sebuah desain jika disandingkan dengan warna dingin. Warna dingin adalah warna-warna dari hijau ke biru, termasuk ungu dan turunannya. Ungu adalah perbatasan antara warna merah dan biru, jika ungu kebiruan maka akan termasuk warna dingin dan jika ungu kemerahan akan termasuk warna hangat. Warna-warna dingin akan member kesant tenang dan mengurangi ketegangan. Dalam desain situs, warna-warna dingin lebih sering diterapkan pada warna latar belakang karena member efek lebih laus pada suatu bidang.

Hal yang harus diperhatikan dalam memilih warna adalah pemilihan warna latar belakang dari halaman situs tersebut. Karena menyangkut area yang cukup luas maka yang perlu dipertimbangkan adalah dari segi efek yang ditimbulkan oleh warna tersebut, tingkat kecemerlangan warna, dan warna yang dipakai oleh elemen visual lainnya dalam situs tersebut. Karena dalam satu halaman situs tidak hanya terdiri dari warna latar belakang dan teks isi saja, tetapi juga akan terdapat visual, simbol, gambar, ataupun logo, maka perlu juga dipertimbangkan tingkat kekontrasannya agar elemen-elemen tersebut masih dapat terlihat di warna latar belakang yang dipilih. Sebagai contoh, untuk pemilihan teks warna merah, akan terlihat cerah ketika dikombinasikan dengan latar belakang berwarna hitam, putih, atau kuning, tetapi akan terlihat suram ketika dikombinasikan dengan warna latar belakang orange, hijau, atau biru. Gambar 3 menjelaskan contoh warna merah yang dipadukan dengan beberapa warna latar belakang akan menghasilkan kesan tingkat kontras yang berbeda-beda.

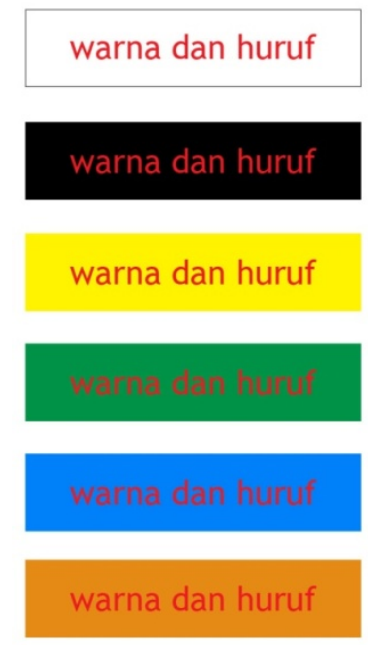

Gambar 3 Warna sebagai Latar Belakang

Tiap warna sebenarnya memiliki tingkat kecerahan masing-masing. Warna putih memiliki tingkat kecerahan yang paling tinggi, sedangkan warna hitam adalah yang tingkat kecerahannya paling rendah. Namun ada beberapa warna yang tingkat kecerahannya hampir mirip satu dengan yang 
lainnya, misalnya hitam dengan biru tua. Tingkat kecerahan ini dapat digunakan untuk membantu pemilihan warna teks dan warna latar belakang pada saat mendesain situs. Kombinasi warna kontras dari warna-wrna primer atau sekunder pada pemilihan warna teks dan latar belakang memang akan membuat teks dalam situs terlihat menonjol dan mudah dibaca, tetapi terlalu banyak dan terlalu sering menggunakan warna kontras akan membuat mata pengunjung situs menjadi cepat lelah karena tingkat kekontrasan kedua warna tersebut sangat tinggi. Jadi sebaiknya jangan terlalu sering menggunakan warna-warna yang terlalu kontras pada layar komputer.

\section{warna dan huruf}

Gambar 4 Teks Dan Latar Belakang Kontras

Sebagai contoh, warna biru muda untuk teks dikombinasikan dengan latar belakang berwarna abu-abu, akan menghasilkan efek teks kurang terbaca dengan jelas, karena rendahnya tingkat kecerahan dari kedua warna tersebut hampir mirip. Begitu pula dengan warna teks biru tua dengan warna hitam sebagai latar belakang, seperti pada Gambar 5.
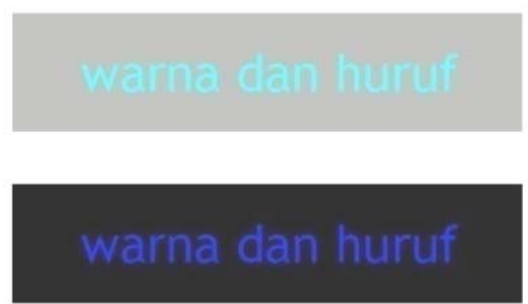

Gambar 5 Tingkat Kecerahan Warna Mirip

Contoh di bawah ini (Gambar 6) adalah teks dan latar belakang menggunakan warna yang tingkat kecerahannya saling melengkapi, artinya jika warna teks yang dipilih adalah warna yang cerah, maka warna latar belakangnya adalah yang tingkat cerahnya medium.

\section{warna dan huruf}

Gambar 6 Tingkat Kecerahan Ideal

\section{Tipografi}

Ada dua jenis bentuk dasar huruf dalam tipografi modern yaitu Serif (huruf dengan kait) dan Sans Serif (huruf tanpa kait), seperti pada Gambar 7. 

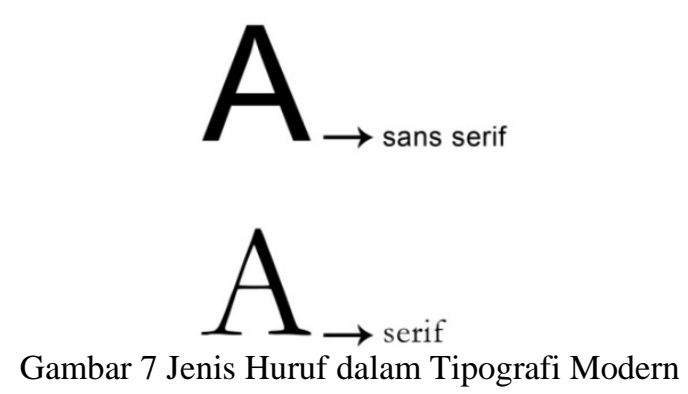

Jenis huruf Serif mempunyai tebal-tipis garis yang jelas dan biasanya jenis huruf ini dipakai pada teks buku dan surat kabar. Sedangkan jenis huruf Sans Serif tidak terlalu jelas tebal-tipis garisnya, kalaupun ada hanyak akan terlihat sedikit sekali perbedaannya. Jenis huruf ini biasanya digunakan pada judul utama, sub judul, dan pada periklanan. Pada ukuran huruf yang normal, jenis huruf Serif adalah yang paling umum digunakan pada desain situs. Tetapi yang harus diperhatikan untuk pemakaian desain situs adalah pemilihan jenis huruf Serif yang kaitnya atau garisnya tidak terlalu tipis agar keterbacaannya lebih mudah.

Selain pemilihan jenis huruf, hal lain yang harus diperhatikan dalam pembuatan desain situs adalah jarak antar baris atau spasi dalam penulisan teks isi situs tersebut. Terkadang ada beberapa situs yang lebih mengutamakan informasi berupa teks saja dan meminimalkan gambar, sehingga akan sangat penting agar pengunjung merasa nyaman dalam membaca teks-teks tersebut agar pesan yang ingin disampaikan dari situs tersebut bias diterima oleh pengunjung. Untuk teks yang panjang, jarak spasi harus lebih dekat dibandingkan dengan teks yang pendek untuk memudahkan mata melihat ke baris berikutnya. Jika jarak spasi terlalu besar, pembaca akan lebih terfokus pada jarak antar baris tersebu bukan pada baris teksnya. Ini merupakan salah satu efek positif negative dari sebuat desain.

Keterbacaan sebuah teks juga dipengaruhi oleh ukuran hurufnya. Untuk huruf yang digunakan di layar komputer tidak sama aturannya dengan yang digunakan di media cetak. Pengaruh cahaya dari komputer membuat mata pembaca menjadi lebih cepat lelah, maka sebaiknya pemilihan huruf tidak terlalu kecil. Semakin kecil huruf yang digunakan di desain situs akan semakin terlihat berbayang tampilan huruf tersebut, sehingga tingkat keterbacaannya semakin kurang juga. Untuk teks pada media cetak minimal ukuran huruf yang masih bias digunakan adalah 8 poin. Sedangkan untuk teks pada komputer minimalnya adalah 10 poin. Judul biasanya 14-18 poin dan sub-judul antara 12-14 poin.

\section{Layout}

Layout adalah tata letak elemen-elemen desain terhadap suatu bidang dalam media tertentu untuk mendukung konsep/pesan yang dibawanya dan dalam hal topik ini adalah media komputer. Elemen-elemen yang biasa digunakan dalam layout sebuah situs tidak jauh berbeda dengan elemen yang digunakan dalam desain media cetak, seperti titik, garis, bidang, warna, tipografi, dan tekstur. Tujuan berbagai elemen tersebut ada dalam layout adalah menyampaikan informasi dengan lengkap dan tepat serta untuk tujuan kenyamanan pengunjung dalam membaca dan mencari informasi di situs tersebut. Layout situs yang baik juga harus memperhitungkan kemudahan navigasi serta estetika dari tiap halamannya.

Desain sebuah situs pasti akan melibatkan elemen garis, yang dapat tampak secara fisik dapat juga tidak. Garis dapat menciptakan kesan estetis pada suatu karya desain. Dalam sebuah situs, garis dapat berfungsi sebagai pembagi suatu area, penyeimbang berat dan sebagai pengikat sistem desain supaya terjaga kesatuannya. Garis yang tidak tampak dalam sebuah desain biasanya digunakan sebagai grid yaitu alat bantu agar tercipta keteraturan dan kerapihan pada saat penempatan beberapa baris teks atau paragraf dengan teks lainnya atau antara beberapa baris teks dengan gambar-gambar, seperti pada Gambar 8-10. 


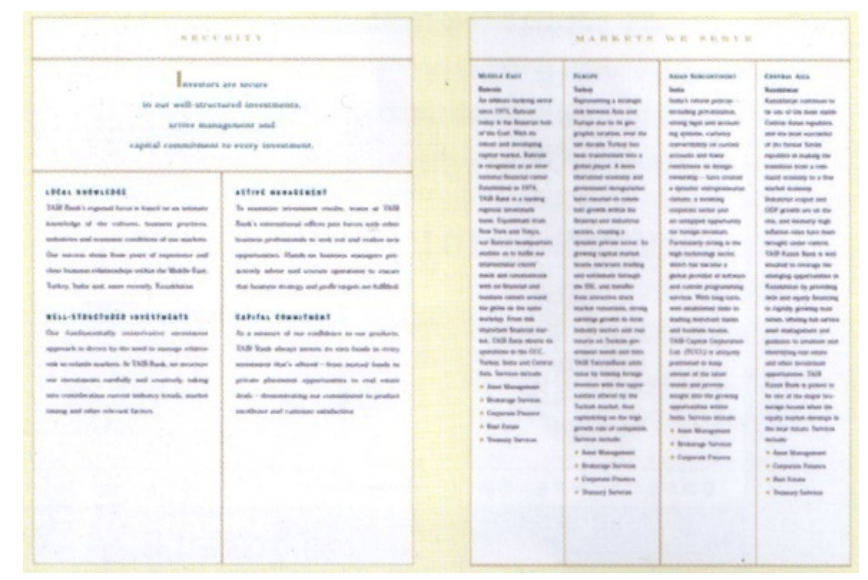

Gambar 8 Fungsi Garis Sebagai Pembagi Area
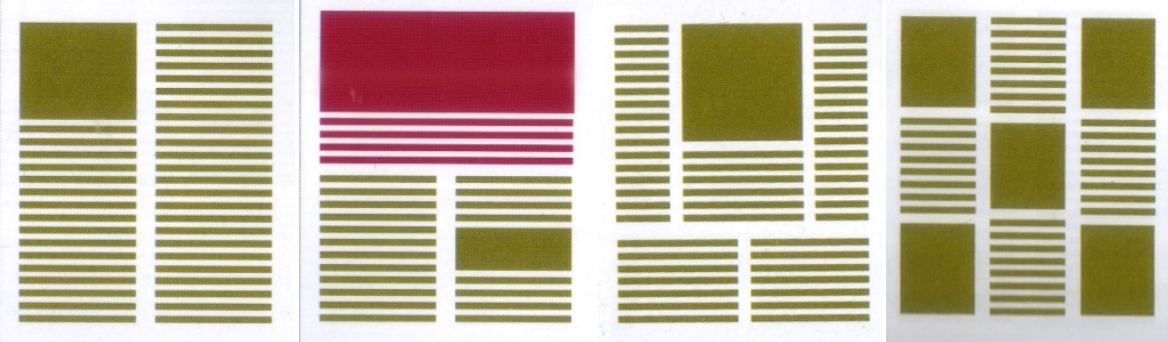

Gambar 9 Fungsi Garis Sebagai Grid
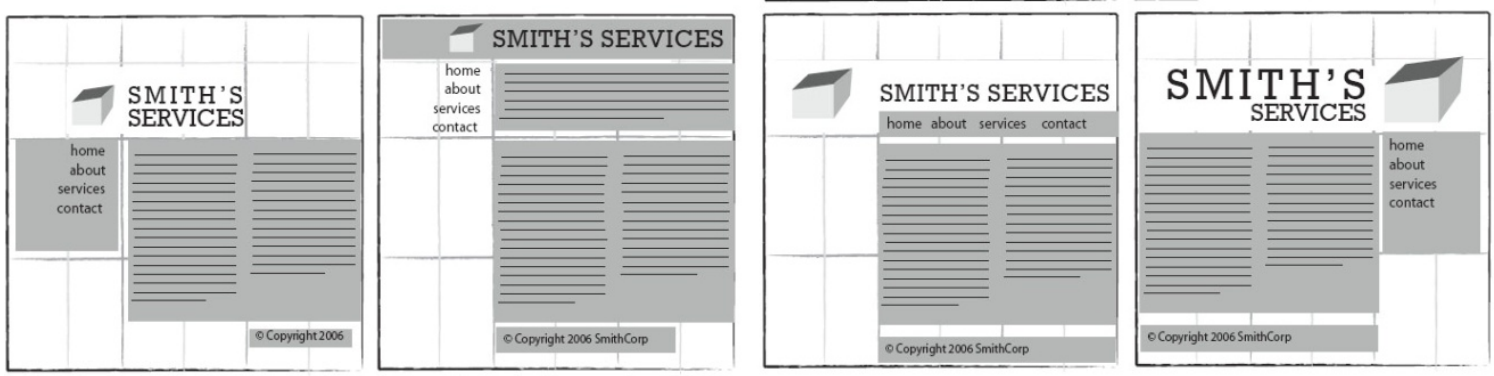

Gambar 10 Contoh Pengaplikasian Grid Pada Desain Situs

Jika dalam desain media cetak, ada yang disebut dengan elemen bidang, maka dalam desain situs yang dibahas kali ini bidang yang berupa gambar. Sebuah situs hampir selalu menyertakan gambar pada beberapa halamannya. Dan besar-kecilnya ukuran file gambar akan mempengaruhi lamanya loading situs tersebut, jadi akan lebih baik jika ukuran file gambar antara 100-200KB saja. Jika memang terpaksa harus menampilkan gambar yang cukup besar ukurannya sehingga loading situs menjadi lama (> 10 detik), maka sebaiknya pada halaman situs tersebut dibuatkan loading bar / progress bar / hourglass icon agar pengunjung tahu bahwa mereka sedang menunggu proses loading / download.

Menu utama atau yang biasa disebut navigasi utama pada sebuah situs menjadi peranan yang cukup penting dalam layout situs tersebut. Menu utama harus terlihat menarik dan dominan agar mata pengunjung dimudahkan dalam navigasi selanjutnya. Dari menu utama inilah pengunjung akan 
'menjelajahi' situs yang mereka lihat. Dan akan lebih baik jika menu utama yang telah dikunjungi atau yang sedang dikunjungi menggunakan warna yang berbeda dengan warna awal menu tersebut, sehingga pengunjung tahu bahwa mereka sedang berada di halaman tersebut atau telah mengunjungi halaman tersebut. Navigasi atau menu sebaiknya diletakkan di paling atas halaman atau di sebelah kiri halaman, karena sesuai dengan arah urutan membaca mata manusia dari atas ke bawah atau dari kiri ke kanan. Sebagai contoh pada Gambar 11.

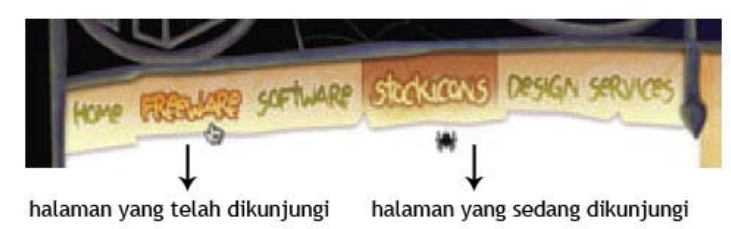

Gambar 11 Contoh Menu Utama

Navigasi utama juga dapat dibuat lebih menarik dengan memberikan efek bayangan/emboss pada tombol menu tersebut, sehingga tombol menu tidak menjadi datar dan kurang terlihat; seperti pada Gambar 12.

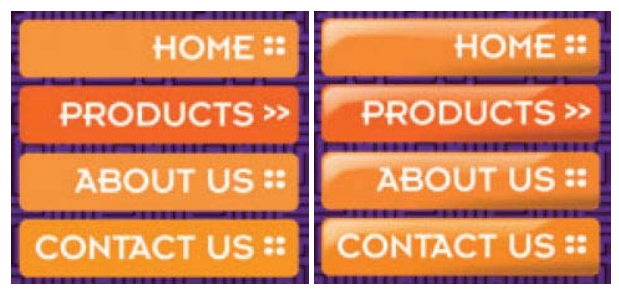

Gambar 12 Contoh Tombol Menu Dengan Efek Emboss

Jika desainer ingin membuat layout untuk beberapa halaman situs, harus diperhatikan prinsip unity atau kesatuan dari tiap halamannya, seperti pada Gambar 13. Hal ini bertujuan agar pengunjung masih bisa merasakan bahwa halaman-halaman yang dikunjungi masih merupakan satu kesatuan situs. Sekreatif dan semenarik apapun desain situs yang dibuat di tiap halamannya harus ada elemen yang menjadi 'benang merah' dari situs tersebut, entah dalam hal kesamaan warna latar belakang, warna menu utama, tata letaknya, penempatan logo, atau hal lainnya, seperti pada Gambar 14.

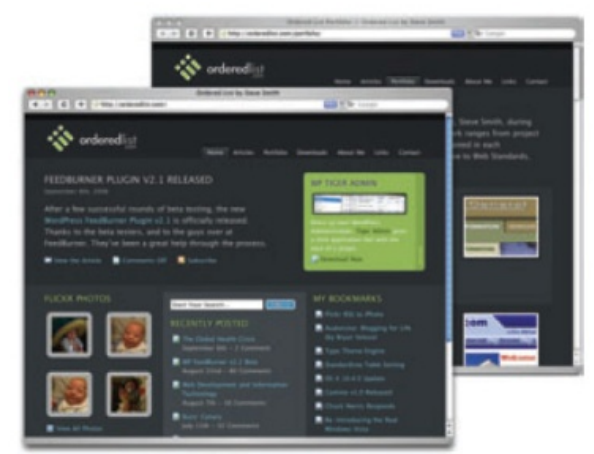

Gambar 13 Contoh Unity Dalam Sebuah Situs 

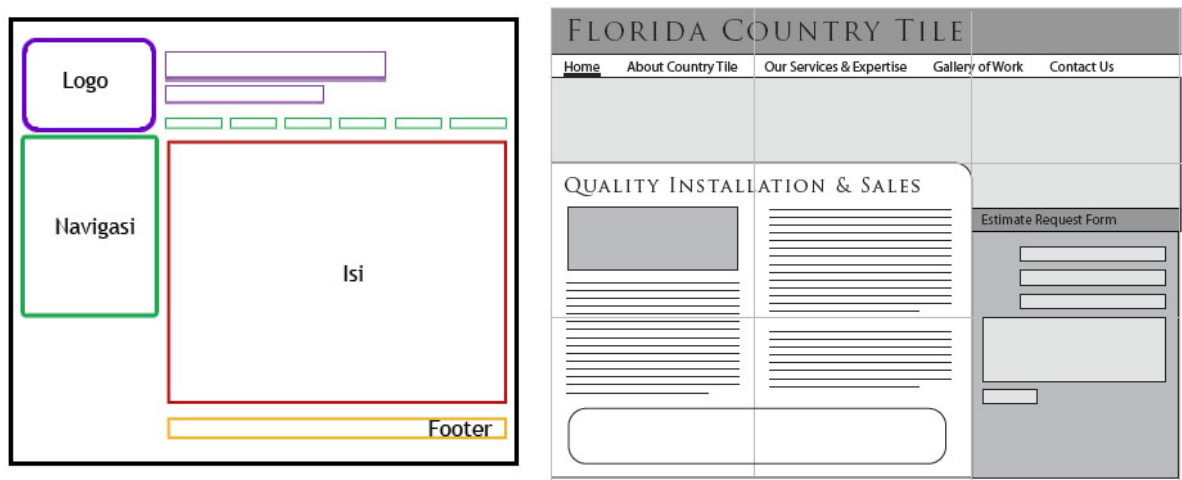

Gambar 14 Contoh Struktur Desain Situs

Keseimbangan (balance) pada sebuah layout juga mempengaruhi desain situs secara keseluruhan. Ada 2 jenis keseimbangan yaitu simetris dan asimetris. Keseimbangan yang simetris adalah membagi dua bidang dengan proporsi yang sama baik horizontal, vertikal, ataupun diagonal (Gambar 15). Sedangkan keseimbangan asimetris adalah membagi bidang dengan proporsi yang berbeda antara satu sisi dengan sisi lainnya (Gambar 16). Desain dengan pola asimetris adalah yang paling sering ditemui dalam desain situs.

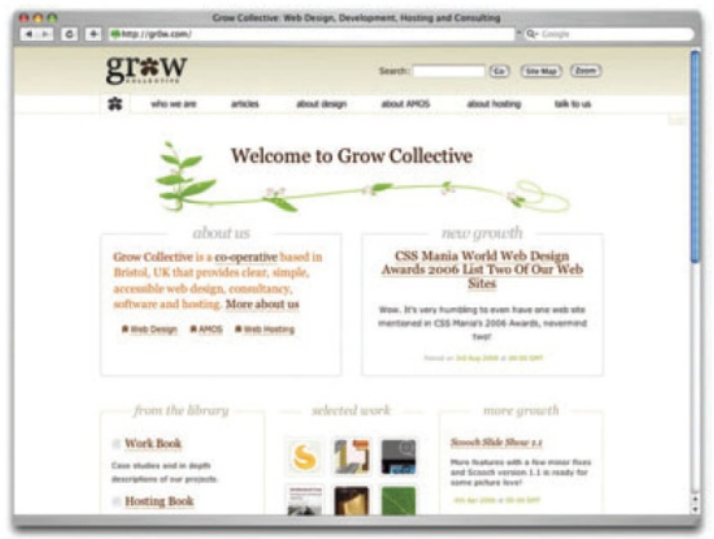

Gambar 15 Keseimbangan Simetris

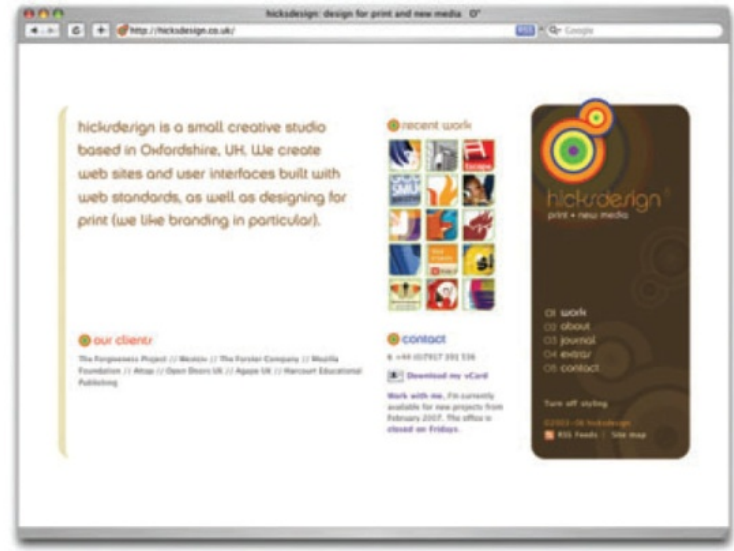

Gambar 16 Keseimbangan Asimetris 


\section{SIMPULAN}

Perkembangan teknologi di dunia maya semakin meningkat pesat, sehingga kebutuhan akan sebuah situs yang menarik dan dapat menyampaikan pesan secara baik pada pengunjung juga akan semakin meningkat. Sehingga menjadi tugas desainer dalam membuat desain sebuah situs dengan segala informasi yang ada di dalamnya dikemas dengan menarik, mudah dibaca, mudah diakses, dan mudah diterima pesannya. Desain situs yang baik mencakup banyak aspek desain, seperti warna yang digunakan untuk latar belakang halaman situs, warna teks, jenis huruf yang digunakan, penggunaan gambar atau foto pendukung, dan penataan layout setiap halaman situs. Dengan menerapkan dasardasar teori desain diharapkan mendesain sebuah situs menjadi lebih baik dan mudah diterapkan.

\section{DAFTAR PUSTAKA}

Beaird, J. (2007). The Principles of Beautiful Web Design. Australia: SitePoint.

Götz, V. (1998). Color \& Type for the Screen. Switzerland: RotoVision SA.

Powell, T. A. (2002). The Complete Reference Web Design Second Edition. USA: McgrawHill/Osborne.

Rustan, S. (2008). Layout Dasar \& Penerapannya. Jakarta: PT Gramedia Pustaka Utama. 